\title{
Hidroksiapatit Dari Tulang Ikan Tuna Sirip Kuning (Tunnus albacores) Dengan Metode Presipitasi
}

\author{
Mutmainnah`, Sitti Chadijah, Wa Ode Rustiah \\ Jurusan Kimia, Fakultas Sains Dan Teknologi, UIN Alauddin Makassar, Makassar \\ email: mutmainnahnuh@gmail.com
}

\begin{abstract}
Indonesia as one of the biggest tuna fish produsers in the world, produce tuna fish bones large enough. Since tuna fish bone contain high calcium it is potentially to be the raw material of hydroxyapatite. Hydroxyapatite are inorganic compounds constituent of bones and teeth has the moleculer formula $\mathrm{Ca}_{5}\left(\mathrm{PO}_{4}\right)_{3} \mathrm{OH}$. Synthesis of hydroxyapatite can be done with precipitation method through tuna fish bone calcination process at the temperature $900^{\circ} \mathrm{C}$ for 5 hours to obtain calcium compounds in the form of calcium oxide. Calcium wich has been obtained added phosphoric acid 0,6 M with flow rate/rapid $1 \mathrm{~mL} /$ minute. Controlled synthesis process parameters are $p H 10$ of solution. Yield of hydroxyapatite generated after synthesis with of the precipitation time 12 hours are of $91.15 \%$. hydroxyapatite product obtained was analyzed by FTIR(Fourier Transform Infrared) and XRD (X-Ray Diffraction). FTIR analysis indicate the presence of $\mathrm{OH}$ groups, $\mathrm{PO}_{4}$ and $\mathrm{CO}_{3}$. Based on the resulting diffraction of XRD analysis, crystallite size obtained each of $211.29 \mathrm{~nm}$ structure is hexagonal. Scherrer method was used to obtain crystallite size.
\end{abstract}

Keywords: calcination, hydroxyapatite, precipitation, tuna fish bone

\section{PENDAHUluan}

Indonesia merupakan negara kepulauan yang berada di antara dua samudera besar yaitu Samudera Pasifik dan Samudera Hindia sehingga memiliki potensi sumber daya perikanan yang besar. Posisi Indonesia yang strategis, jelas sangat menguntungkan untuk menjadi produsen tuna di dunia. Hal ini terjadi karena massa air barat dan timur yang melintas di Samudera Hindia dengan membawa partikel kaya akan makanan biota laut. Kemudian, arus Kuroshio, yaitu North Equatorial dan South Equatorial Current di Samudera Pasifik merupakan wilayah yang kaya akan bahan makanan serta mempunyai suhu, salinitas dan beberapa faktor oseanografis yang disukai oleh ikan tuna (Rahajeng, 2012).

Ikan tuna merupakan ikan yang memiliki nilai jual tinggi dan termasuk jenis ikan yang paling banyak dicari dari laut Indonesia. Itu disebabkan rasanya yang lezat. Namun, bagian ikan tuna yang dapat dimakan hanya berkisar antara 50\% - 60\% berupa daging. Hal ini menyebabkan diperoleh hasil samping berupa kepala, sisik kulit dan tulang. Tulang dan kepala ikan merupakan hasil samping yang mendominasi baik dari skala industri maupun rumah tangga (Murniyati, \& Rosmawaty, 2014). 
Tulang ikan tuna sebagai salah satu limbah terbesar dari industri pengolahan ikan tuna, akan memberikan dampak yang kurang baik terhadap lingkungan jika tidak dimanfaatkan. Hal ini terjadi karena dapat menimbulkan pencemaran. Padahal tulang ikan mengandung mineral yang cukup tinggi dibandingkan dengan bagian tubuh yang lain karena unsur utama dari tulang ikan adalah kalsium, fosfor dan karbonat (Trilaksani, Salamah \& Nabil, 2006). Tulang ikan mengandung 60-70\% mineral dengan komponen penyusun berupa $30 \%$ protein kolagen dan sebagian besar bioapatit, termasuk hidroksiapatit, carbonated apatite atau dahlite (Riyanto, Maddu \& Rahman, 2013). Pemanfaatan limbah tulang ikan tuna dalam industri pengolahan tepung sebagai sumber kalsium $(\mathrm{Ca})$ merupakan salah satu alternatif dalam rangka menyediakan sumber pangan kaya akan kalsium (Ca) sekaligus mengurangi dampak buruk pencemaran lingkungan akibat dari pembuangan limbah industri pengolahan tuna (Trilaksani, Salamah \& Nabil, 2006). Melalui pendekatan teknologi yang tepat, tulang ikan tuna sirip kuning (Thunnus albacores) dapat diolah menjadi produk yang memiliki nilai ekonomi yang tinggi berupa hidroksiapatit $\left(\mathrm{Ca}_{5}\left(\mathrm{PO}_{4}\right)_{3}(\mathrm{OH})\right)$

Produk tulang ikan berupa hidroksiapatit $\left(\mathrm{Ca}_{5}\left(\mathrm{PO}_{4}\right)_{3}(\mathrm{OH})\right)$ merupakan unsur anorganik alami yang berasal dari tulang yang dapat dimanfaatkan untuk regenerasi tulang, memperbaiki, mengisi, memperluas dan merekonstruksi jaringan tulang. Hal ini dikarenakan hidroksiapatit memiliki sifat biokompatibiltas yang sempurna apabila diimplankan pada tulang. Selain itu, hidroksiapatit juga dapat digunakan sebagai adsorben untuk mengatasi pencemaran lingkungan terhadap logam berat (Aisyah, et. al., 2012).

Hidroksiapatit untuk aplikasi industri umumnya diperoleh dengan metode sintetis. Beberapa metode sintetis yang digunakan untuk menghasilkan hidroksiapatit antara lain hidrotermal, elektrodeposisi, sol gel dan presipitasi (Nayak \& Kumar, 2010).

Metode presipitasi merupakan metode yang paling sering digunakan karena dianggap paling seerhana untuk sintesis hidroksiapatit (Mohammad, Othman \& Yee-Yeoh, 2014). Stabilitas hidroksiapatit yang disintesis melalui metode presipitasi mudah dipengaruhi oleh $\mathrm{pH}$, sehingga perlu dilakukan penambahan larutan yang bersifat basa hingga mencapai $\mathrm{pH} 10$. Endapan yang diperoleh dikeringkan pada suhu kamar hingga kadar airnya berkurang 30\%. Butiran yang diperoleh dengan ukuran 0.5 hingga $2 \mathrm{~mm}$ kemudian dikalsinasi pada suhu $900^{\circ} \mathrm{C}$ selama \pm 4 jam (Ignjatovic, et.al., 1999).

\section{METODE PENELITIAN}

\section{Alat}

Alat yang digunakan dalam penelitian ini yaitu, Fourier Transform Infrared (FTIR) Shimadzu Prestige-21, X-ray Diffraction (XRD) Shimadzu Maxima-X, Energy Dispersive X-Ray Flouresence (EDXRF) Thermo scientific Arl Quant'X, tanur Thermo Scientific Heraeus, ayakan Retsch Sieve and Shaker AS 200 basic, stirring hot plate Thermo Scientific Cimarec, neraca analitik, desikator, oven, corong Buchner, buret, labu takar $1000 \mathrm{~mL}$, gelas kimia $300 \mathrm{~mL}$, gelas ukur $100 \mathrm{~mL}$, lumpang dan mortar, statif dan klem, batang pengaduk, spatula, pipet tetes, pinset. 


\section{Bahan}

Bahan yang digunakan dalam penelitian ini yaitu aquades $\left(\mathrm{H}_{2} \mathrm{O}\right)$, asam posfat $\left(\mathrm{H}_{3} \mathrm{PO}_{4}\right)$, aseton $\left(\mathrm{CH}_{3} \mathrm{COCH}_{3}\right)$, kertas indikator $\mathrm{pH}$ universal, kertas saring whatman no. 42, natrium hidroksida $(\mathrm{NaOH})$, limbah tulang Ikan Tuna Sirip Kuning.

\section{Prosedur Kerja}

\section{Preparasi Sampel}

Tulang ikan dicuci dengan air keran dan direbus selama \pm 2 jam, kemudian dipotong-potong dan dikeringkan selama 14 hari dengan sinar matahari. Setelah itu, tulang ikan dibersihkan dari jaringan lunak dan dicuci dengan aquades. Kemudian dikeringkan dengan sinar matahari. Setelah kering, tulang ikan tuna direndam dengan aseton $\left(\mathrm{CH}_{3} \mathrm{COCH}_{3}\right)$ selama 3 x 24 jam (setiap 1 x 24 jam dilakukan penggantian pelarut) dan diuapkan pada suhu kamar hingga aroma asetonnya hilang. Setelah itu, tulang ikan tuna dipanaskan dengan oven selama 4 jam pada suhu $105^{\circ} \mathrm{C}$ dan ditempa menjadi bagian-bagian yang lebih kecil.

\section{Pembuatan Kalsium Oksida (CaO)}

Tulang ikan tuna ditimbang sebanyak 80.04 gram dan dioven selama 2 jam. Setelah itu, tulang ikan tuna dikalsinasi pada suhu $900^{\circ} \mathrm{C}$ selama 5 jam. kemudian timbang bobot sampel dan haluskan dengan lumpang dan alu. Kemudian ayak dengan ayakan 125 mesh. Serbuk CaO yang dihasilkan dianalisis dengan Energy Dispersive X-Ray Flouresence (EDXRF ).

\section{Analisis dengan $\mathrm{XRF}$}

Alat dan monitor dinyalakan sehingga di monitor akan muncul tampilan display untuk langkah pengoperasian alat XRF. Sebelum alat dioprasikan, terlebih dahulu dilakukan kalibrasi alat. Ketika XRF dioperasikan spinner sampel holder akan bergerak menuju holder dan berhenti secara otomatis. Tampilan display digital DX-95 akan menunjukkan angka. Kondisi pengukuran pada tegangan $14 \mathrm{kV}$ dan kuat arus $90 \mu \mathrm{A}$. Pengukuran sampel akan terjadi hingga 5 menit.

\section{Sintesis Hidroksiapatit}

$\mathrm{CaO}$ ditimbang sebanyak 7,4094 gram. Kemudian dimasukkan dalam gelas kimia $300 \mathrm{~mL}$ dan ditambahkan $100 \mathrm{~mL}$ aquades sehingga akan terbentuk suspensi. Setelah itu, dilakukan pengadukan dengan kecepatan $700 \mathrm{rpm}$ selama 1 jam pada suhu $90^{\circ} \mathrm{C}$ dan ditambahkan dengan larutan asam posfat $0,6 \mathrm{M}$ sebanyak $100 \mathrm{~mL}$ secara perlahan dengan kecepatan $1 \mathrm{~mL} / \mathrm{menit}$ menggunakan buret. Setelah larutan asam posfatnya habis, dilakukan pengadukan lanjutan kecepatan $700 \mathrm{rpm}$ selama 1 jam pada suhu $90^{\circ} \mathrm{C}$. $\mathrm{pH}$ larutan diatur dengan menggunakan larutan natrium hidroksida $(\mathrm{NaOH}) 1 \mathrm{M}$ hingga mencapai $\mathrm{pH}$ 10. Setelah itu, larutan didiamkan selama, 12, 24, 36, 48 dan 60 jam sehingga akan terbentuk endapan. Endapan yang diperoleh disaring dengan menggunakan corong buchner \pm 4 jam dan dicuci dengan aquades sebanyak 3 kali pencucian. Setelah itu, endapan dipanaskan selama 2 jam pada suhu $105^{\circ} \mathrm{C}$ dan dipanaskan 
pada suhu $900^{\circ} \mathrm{C}$ selama 5 jam. Bobot serbuk yang dihasilkan kemudian ditimbang. Setelah itu, rendmen dari hidroksiapatit yang dieroleh dihitung.

\section{Analisis dengan FTIR}

Sampel dalam bentuk serbuk digerus hingga memenuhi ukuran partikel kurang dari $2 \mu \mathrm{m}$. kemudian dimasukkan ke dalam pellet press secara merata. Pellet press dihubungkan dengan pompa kompersi hydraulic serta pompa vakum selama 15 menit. Pellet yang terbentuk diusahan memiliki ketebalan $0.3 \mathrm{~mm}$ (transparan). Selanjutnya pellet dibuka secara hati-hati dan dipindahkan ke dalam sle holder menggunakan spatula. Setelah itu, alat diatur dengan dengan kecepatan normal dan ekspansi transmisi $100 \mathrm{x}$. setelah itu, dilakukan analisa gugus fungsi.

\section{Analisis Hidroksiapatit dengan XRD}

Sebelum digunakan alat dikalibrasi terlebih dahulu dan XG kontrol (berupa arus), water flow, shutter dan door open diatur. Sambil menunggu kalibrasi alat, sebanyak $2 \mathrm{mg}$ sampel ditempatkan di dalam holder pada difraktometer. Tegangan yang digunakan adalah $40 \mathrm{Kv}$ dan arus generatornya sebesar $30 \mathrm{~mA}$ dengan sumber panjang gelombang sebesar 1,5406 ̊. Hasil yang diperoleh berupa difraktogram yang teridentifikasi berdasarkan intensitas dan sudut $2 \theta$. Penentuan fase muncul mengacu pada Joint Committee on Powder Diffraction Standart (JCPDS).

\section{HASIL DAN PEMBAHASAN}

\section{Kandungan Senyawa yang Terdapat pada Tulang Ikan Tuna Sirip Kuning}

Berdasarkan hasil analisis XRF diperoleh beberapa komponen-komponen senyawa yang terdapat pada tulang ikan tuna. Sebagaimana yang ditunjukkan Tabel 1.

Tabel 1. Senyawa dalam Tulang Ikan Tuna Sirip Kuning Hasil Kalsinasi Berdasarkan Data Analisis XRF

\begin{tabular}{cc}
\hline Senyawa & Konsentrasi $(\% \mathbf{b} / \mathbf{b})$ \\
\hline $\mathrm{CaO}$ & 62,31 \\
$\mathrm{P}_{2} \mathrm{O}_{5}$ & 37,46 \\
$\mathrm{SrO}$ & 0,186 \\
$\mathrm{Nb}_{2} \mathrm{O}_{5}$ & 0,0162 \\
$\mathrm{MoO}_{3}$ & 0,0098 \\
$\mathrm{Sb}_{2} \mathrm{O}_{3}$ & 0,0061 \\
$\mathrm{In}_{2} \mathrm{O}_{3}$ & 0,0061 \\
$\mathrm{SnO}_{2}$ & 0,0059 \\
\hline
\end{tabular}

Limbah tulang ikan tuna sirip kuning dikelompokkan ke dalam bagian limbah tulang ikan yang memiliki kadar minyak terbesar jika dibandingkan dengan kepala dan kulit (Defandi, 
2015). Dimana, minyak merupakan suatu senyawa yang bersifat nonpolar sehingga untuk menarik senyawa tersebut diperlukan pelarut yang sifatnya sama dengan minyak yaitu aseton $\left(\mathrm{CH}_{3} \mathrm{COCH}_{3}\right)$. Salah satu metode yang digunakan untuk menarik senyawa dalam suatu bahan adalah maserasi. Maserasi merupakan proses perendaman sampel menggunakan pelarut organik pada suhu ruang. Selanjutnya, tulang ikan tuna yang telah dimaserasi dipisahkan dari pelarutnya dan dibiarkan di udara. Hal ini bertujuan agar pelarut yang masih terdapat pada tulang ikan tuna dapat menguap sempurna. Tulang ikan tuna yang diperoleh mengalami perubahan warna dari cokelat menjadi kuning. Hal ini menunjukkan bahwa aseton benar-benar menarik minyak yang terkandung dalam tulang ikan tuna. Selain itu, warna kuning yang masih melekat pada tulang ikan tuna menunjukkan bahwa masih ada senyawa organik (minyak dan kolagen) yang terkandung di dalamnya.

Kalsium yang terdapat dalam tulang ikan tuna berbentuk persenyawaan kalsium karbonat $\left(\mathrm{CaCO}_{3}\right)$, sehingga diperlukan proses lanjutan berupa kalsinasi untuk memperoleh kalsium oksida $(\mathrm{CaO})$. Kalsinasi merupakan proses pemecahan suatu senyawa melalui pemanasan suhu tinggi yang menyebabkan terjadinya reaksi dekomposisi. Dalam hal ini, kalsium karbonat yang dipanaskan akan terurai, sebagaimana yang ditunjukkan reaksi berikut:

$$
\mathrm{CaCO}_{3} \longrightarrow \mathrm{CaO}+\mathrm{CO}_{2}
$$

Reaksi di atas menunjukkan kalsium karbonat terurai menjadi kalsium oksida dan karbon dioksida $\left(\mathrm{CO}_{2}\right)$, dimana karbon dioksida akan menguap di udara.

Tulang ikan tuna yang telah dikalsinasi mengalami penurunan bobot rata-rata sebesar $44,68 \%$ dan mengalami perubahan warna dari putih kekuning-kuningan menjadi putih. Penurunan bobot yang terjadi menandakan adanya pelepasan unsur yang terdapat dalam tulang ikan tuna sirip kuning. Menurut Ozawa (2007) dalam Riyanto (2013: 124), mengatakan bahwa sampel yang dikalsinasi suhu tinggi $(700-900)^{\circ} \mathrm{C}$ akan berwarna putih yang menandakan proses degradasi material organik sudah tidak lagi terjadi. Untuk memastikan bahwa hasil yang diperoleh dari proses kalsinasi adalah kalsium oksida, maka dilakukan analisis dengan menggunakan Energi Dispersive X-Ray Flouresence (EDXRF). Hasil analisis menunjukkan ada sekitar 62,31\% kalsium oksida yang terdapat dalam tulang ikan tuna. Menurut Nagai (2004) dalam Kim dan Mendis (2006), komponen organik berupa kolagen yang terdapat dalam tulang ikan meliputi 30\% dan sisanya 60-70\% merupakan komponen anorganik berupa kalsium.

\section{Rendamen Serbuk Hasil Sintesis}

Tabel 2. Rendamen Hasil Sintesis Hidroksiapatit Berdasarkan Lama Pengendapan

\begin{tabular}{cc}
\hline Lama waktu pendiaman (jam) & Rendamen $(\boldsymbol{\%} \mathbf{b} / \mathbf{b})$ \\
\hline 12 & 91,15 \\
24 & 91,24 \\
36 & 91,39 \\
48 & 91,55 \\
\hline
\end{tabular}


Berdasarkan Tabel 2 sintesis hidroksiapatit yang dilakukan dengan metode presipitasi menunjukkan adanya sedikit perbedaan rendamen seiring dengan lamanya waktu pengendapan. Rendamen merupakan bobot relatif serbuk hidroksiapatit setelah dilakukan sintesis terhadap bobot serbuk kalsium oksida sebelum dilakukan sintesis. Tendamen dihitung dengan rumus sebagai berikut:

$$
\text { rendamen }=\frac{\text { bobot akhir sampel }}{\text { bobot awal sampel }} \times 100 \%
$$

Menurut Andika (2015: 7), semakin lama waktu pengendapan, maka hasil yang diperoleh juga akan semakin banyak. Hal ini terjfi karena semakin lama waktu yang dibutuhkan untuk membiarka endapan terendam, maka potensi untuk mencapai kesetimbangan juga akan semakin besar.

\section{Karakterisasi dengan FTIR}

Berdasarkan hasil analisis dengan FTIR diperoleh gugus hidroksil $(\mathrm{OH})$ ' fosfat $\left(\mathrm{PO}_{4}\right)$ dan karbonat $\left(\mathrm{CO}_{3}\right)$. Rentang bilangan gelombang dan gugus fungsi yang ada pada FT-IR dapat dilihat pada Tabel 3 .

Tabel 3. Spektrum hasil uji FTIR

\begin{tabular}{cccccc}
\hline \multirow{2}{*}{ Gugus } & \multicolumn{5}{c}{ Bilangan Gelombang $\left(\mathrm{cm}^{-1}\right)$} \\
\cline { 2 - 6 } & 12 jam & 24 jam & 36 jam & 48 jam & 60 jam \\
\hline$(\mathrm{OH})^{-}$ & 3568,31 & 3570,24 & $35,70,24$ & 3568,31 & 3568,38 \\
\hline & 570,93 & 570,93 & 572,86 & 570,93 & 570,93 \\
$\left(\mathrm{PO}_{4}\right)^{3-}$ & 601,79 & 601,79 & 601,79 & 601,79 & 601,79 \\
& 1053,13 & 1051,20 & 1053,13 & 1041,56 & 1049,28 \\
& 1091,71 & 1093,64 & 1093,64 & 1093,64 & 1093,64 \\
\hline \multirow{2}{*}{$\left(\mathrm{CO}_{3}\right)^{2-}}$. & 1419,61 & 1413,82 & 1415,75 & 1421,54 & 1419,61 \\
& 1454,33 & 1454,33 & 1454,33 & 1456,26 & 1454,33 \\
\hline
\end{tabular}

Berdasarkan tabel 3.3 karakterisasi dengan FTIR dari 12, 24, 36, 48 dan 60 jam masingmasing menunjukkan adanya gugus $\mathrm{OH}$ dan $\mathrm{PO} 4$. Namun gugus $\mathrm{OH}$ yang dihasilkan memiliki intensitas pita serapan yang lemah dan tidak lebar. Menurut Fessenden dan Joan (1992: 320), jika pita serapan $\mathrm{OH}^{-}$yang muncul lemah dan berbentuk runcing, maka dianggap bahwa ikatan hidrogen yang ada tidak ekstensif. Selain itu, masing-masing spektrum juga menunjukkan keberadaan $\mathrm{CO}_{3}{ }^{2-}$. Menurut Kahrizsangi, dkk (2011: 541), mengatakan bahwa keberadaan ion 
Mutmainnah, Chadijah,

S. \& Rustiah, W.O.

karbonat yang terdapat berasal dari tulang ikan yang tidak terdekomposisi sempurna pada saat kalsinasi.

\section{Karakterisasi dengan XRD}

Berdasarkan hasil analisis dengan menggunakan XRD maka diperoleh beberapa karakteristik dari senyawa yang dihasilkan sebagaimana yang terdapat dalam Tabel 4.

Tabel 4. Bentuk dan Ukuran Kristal Berasarkan Analisis XRD

\begin{tabular}{ccc}
\hline Lama pengendapan (jam) & Ukuran Kristal (nm) & Jenis senyawa \\
\hline 12 & 211.29 & HAp \\
24 & 91.14 & HAp \\
36 & 78.24 & HAp dan FAp \\
48 & 54.41 & FAp \\
60 & 33.95 & FAp \\
\hline
\end{tabular}

Keterangan:

HAp : Hidrosiapatit

FAp : Flouroapatit

Hasil karakterisasi XRD dapat digunakan untuk menentukan ukuran kristal dengan menggunaan persamaan Schereer:

$$
\tau=\frac{k \lambda}{B \cos \theta}
$$

Ukuran kristal dan senyawa yang diperoleh berdasarkan lama pengendapan ditunjukkan pada Tabel 4. Flouroapatit yang dihasilkan terbentuk dari senyawa kalsium florida $\left(\mathrm{CaF}_{2}\right)$ yang terdapat dalam tulang ikan. Menurut Wijaya (2010), tulang ikan tuna mengandung persenyawaan kalsium berupa, 58,3\% kalsium fosfat, 3,83 kalsium karbonat dan 1,9\% kalsium florida. Sehingga dapat dikatakan bahwa lama pengendapan berpengaruh terhadap ukuran kristal dan senyawa yang terbentuk. Dimana semakin lama waktu yang dibutuhkan untuk terjadi pengendapan maka kristal yang diperoleh juga akan semakin kecil. Sedangkan untuk senyawa, semakin lama waktu yang dibutuhkan untuk terjadi pengendapan maka potensi untuk menghasilkan flouroapatit juga akan semakin besar. Hal ini terjadi karena pada proses pengendapan suatu endapan, suatu zat yang biasanya dapat larut akan terbawa mengendap dan peristiwa ini disebut kopresipitasi. Kopresipitasi dapat terjadi karena terbentuknya kristal campuran yang memasuki kisi kristal endapan. 


\section{PENUTUP}

\section{Kesimpulan}

Berdasarkan hasil penelitian yang telah dilakukan, dapat disimpulkan bahwa rendamen hidroksiapatit yang dihasilkan dari serbuk kalsium oksida yang berasal dari tulang ikan tuna pada 12, 24, 36, 48 dan 60 jam masing-masing sebesar 91,15\%, 91,24\%, 91,39\%, 91,55\% dan 91,80\%.. Ukuran kristal yang dihasilkan dari setiap variasi lama waktu pendiaman masingmasing sebesar $211,2914 \mathrm{~nm}, 91,1442 \mathrm{~nm}, 78,2476 \mathrm{~nm}, 54,4136 \mathrm{~nm}$ dan 33,9564 nm. Selain itu, masing-masing kristal yang dihasilkan berbentuk heksagonal.

\section{DAFTAR PUSTAKA}

Aisyah, D., Mamat, I., Sontang, M., Rosufila, Z. \& Ahmad, N.M. (2012). Program pemanfaatan sisa tulang ikan untuk produk hidroksiapatit: Kajian di pabrik pengolahan kerupuk lekop Kuala Trengganu-Malaysia. Jurnal Sosioteknologi, 26, 129-141.

Andika, R, Fadli, A. \& Irdoni HS. (2015). Pengaruh waktu aging dan kecepatan pengadukan pada sintesis hidroksiapatit dari cangkang telur dengan metode presipitasi. JOM FTeknik, 2(1), 1-8.

Defandi, F. (2015). Sifat fisiko kimia minyak ikan dari limbah pengolahan ikan tuna (Thunnus $s p)$. Skripsi, Universitas Andalas, Padang.

Ebrahimi-Kahrizsangi, R. \& Nasiri-Tabrizi, B. (2011). Characterization of crystal fluoroapatite nanoparticles synthesized via mechanochemical method. Particuology,.9(5), 537-544.

Kim, S \& Mendis, E. (2006). Bioactive compounds from marine processing by products-a review. Food Research International. 39, 383-393.

Ignjatovic, N., Tomic, S., Dakic, M., Miljkovic, M., Plavsic, M., \& Uskokovic, D. (1999). Synthesis and properties of hydroxyapatite/poly-L-lactide composite biomaterials. Journal Biomaterials, 20(9), 809-816.

Mohammad, N.F., Othman, R. \& Yee-Yeoh, F. (2014). Nanoporous hydroxyapatite preparation methods for drug delivery application”. Red. Adv. Mater. Sci.38, 138-147.

Murniyati, Dewi, F.R. \& Rosmawaty . (2014). Teknik Pengolahan Tepung Kalsium Dari Tulang Ikan Nila. Jakarta, Penebar Swadaya.

Nayak \& Kumar, A. (2010). Hydroxyapatite synthesis methodologies: An overview. International Journal of ChemThech Research. 2(2), 903-907.

Rahajeng, M. (2012). Ikan tuna Indonesia. Warta Ekspor Kementerian Pedagangan. 6(3), 1-20.

Riyanto, B., Maddu, A. \& Nurrahman. (2013). Material biokeramik berbasis hidroksiapatit tulang ikan tuna. JPHPI, 16(2), 119-132.

Rujitanapanich, S., Kumpapan, P. \& Wanjanoi. P. (2014). Synthesis of hidroxyapatite from oyster shell via precipitation. Energy Procedia. 56, 112-117.

Trilaksani, W., Salamah, E. \& Nabil, M. (2006). Manfaat limbah tulang ikan tuna (Thunnus sp.) sebagai sumber kalsium dengan metode hidrolisis protein. Buletin Hasil Perikanan. 9(2), $36-45$. 